\title{
PENGEMBANGAN MODEL PERMAINAN "TEMBAK KALENG" SEBAGAI ALTERNATIF VARIASI PERMAINAN BOLA KECIL DALAM PEMBELAJARAN PENJASORKES BAGI SISWA KELAS VIII SMP NEGERI 6 TEBING TINGGI
}

\author{
Ontong Sinaga
}

Surel: ontongsinaga222@gmail.com

\begin{abstract}
ABSTRAK
Penelitian ini bertujuan untuk menghasilkan produk model permainan "Tembak Kaleng" sebagai alternatif variasi permainan bola kecil dalam pembelajaran Penjasorkes bagi siswa kelas VIII. Desain uji coba menggunakan desain eksperimental dengan dua tahap: 1) skala kecil 16 siswa, 2) skala besar 34 siswa. Subjek uji coba adalah sasaran pemakaian produk, yaitu siswa kelas VIII SMP N 6 Tebing Tinggi. Teknik pengumpulan data yang digunakan dalam penelitian ini yaitu data kualitatif dan kuantitatif. Hasil yang diperoleh berdasarkan hasil uji coba skala kecil persentase jawaban sangat baik $(70,8 \%)$, baik $(18,75 \%)$ dan kurang baik $(10,42)$. Hasil uji coba skala besar dengan persentase jawaban sangat baik $(87,25 \%)$, baik $(7,84 \%)$, dan kurang $(4,9 \%)$. Sedangkan persentase yang diperoleh dari hasil data evaluasi ahli yaitu ahli penjas masuk dalam kategori baik (77,33\%), ahli pembelajaran I masuk katagori baik (90,67\%), ahli pembelajaran II masuk katagori cukup baik $(65,33 \%)$.
\end{abstract}

Kata kunci : Pengembangan, Permainan, Bola Kecil, Tembak Kaleng

\section{PENDAHULUAN}

Pelaksanaan pendidikan jasmani, kesehatan, olahraga dan rekreasi di sekolah menengah pertama (SMP) selama ini masih jauh dari tujuan pendidikan jasmani itu sendiri. Banyak sekali faktorfaktor yang menjadi penyebabnya, diantaranya adalah kurangnya sarana prasarana yang memadai, kurangnya kompetensi guru dll. Permasalahan tersebut dapat diatasi dengan berbagai cara, salah satunya adalah dengan memodifikasi pembelajaran penjasorkes dengan syarat tujuan penjasorkes yang sebenarnya masih dapat tercapai. Kurikulum standar pendidikan jasmani, olahraga dan kesehatan sekolah menengah pertama kelas VIII semester 1 dengan standar isi Mempraktikkan kombinasi teknik dasar salah satu permainan dan olahraga beregu bola kecil lanjutan dengan kombinasi yang baik serta nilai kerjasama, toleransi, percaya diri, keberanian, menghargai lawan, bersedia berbagi tempat dan peralatan (Samsudin, 2008:130). Berdasarkan observasi dan wawancara yang dilakukan di $\begin{array}{lllll}\text { SMP } & \mathrm{N} & 6 & \text { Tebing Tinggi yang }\end{array}$ terletak di Jl. Jalan Jend. Gatot Subroto, Pabatu, Kec. Padang Hulu, Kota Tebing Tinggi ditemukan adanya potensi-potensi yang perlu dikembangkan mengenai pada pelaksanaan pembelajaran Penjasorkes pada siswa kelas VIII khusunya dalam materi pembelajaran permainan bola kecil. Hasil wawancara yang dilakukan oleh penulis dengan guru mata pelajaran 
Ontong Sinaga : Pengembangan Model Permainan ...

Penjasorkes di SMP tersebut permainan bola kecil belum pernah diajarkan kepada siswa. Hal ini disebabkan minimnya sarana prasarana yang memadai untuk mengajarkan siswa permainan bola kecil, misalnya softball, tenis lapangan, bulutangkis dll. Materi permainan bola kecil seharusnya bisa diajarkan kepada siswa karena sesuai dengan kurikulum standar isi Penjasorkes. Selain minimnya prasarana yang memadai, antusiasme siswa dalam mengikuti pembelajaran penjasorkes juga kurang. Hal ini dibuktikan pada saat observasi ditemukan siswa yang kurang bersemangat dalam mengikuti pembelajaran Penjasorkes. Sehingga berdasarkan permasalahanpermasalahan tersebut diatas dapat disimpulkan bahwa pembelajaran di $\begin{array}{lllll}\text { SMP } & \mathrm{N} & 6 & \text { Tebing Tinggi tidak }\end{array}$ berjalan dengan baik karena minimnya sarana prasarana dan kurangnya variasi dalam pembelajaran Penjasorkes. Masalah tersebut dapat diatasi dengan variasi pembelajaran melalui pengembangan model permainan tembak kaleng. Produk permainan Tembak Kaleng merupakan pengembangan model permainan yang akan dijadikan alternatif variasi permainan bola kecil dalam pembelajaran penjasorkes. Permainan ini merupakan permainan olahraga bola kecil beregu yang bisa dimainkan oleh 8 sampai 10 orang siswa per tim. Pada dasarnya permainan ini mengadopsi permainan rounders yang prinsipnya adalah menggunakan bola kecil dan regu yang paling banyak mengelilingi lapangan permainan dinyatakan sebagai pemenang, sehingga membutuhkan kerja sama dan kekompakkan para pemain. Permainan Tembak Kaleng mempunyai karakteristik permainan yang mirip dengan permainan rounders yang mempunyai jarak antar base sepanjang 15 meter, hanya saja jika rounders memiliki 5 base, hal ini berbeda dengan permainan Tembak Kaleng yang hanya memiliki 4 base. Perbedaan yang mencolok adalah cara memulai permainan, jika rounders mengawalai permainan dengan cara lemparan pitcher yang di arahkan ke batter untuk di pukul, berbeda halnya dengan Tembak kaleng yang mengawali permainan dengan cara menembak susunan kaleng dengan bola tonis. Cara mengawali permainan yang demikian adalah yang menjadi alasan mengapa permainan ini diberi nama Tembak Kaleng. Tujuan permainan tembak Kaleng ini meliputi domain psikomotorik seperti perkembangan keterampilan gerak dasar dan kebugaran jasmani, domain kognisi seperti kemampuan memecahkan masalah serta domain afektif seperti kekompakan, kerjasama dan mau berbagi tempat/ peralatan. Hal ini sesuai dengan tujuan pendidikan jasmani menurut Husdarta (2009:9) yang diringkas dalam terminologi populer, maka tujuan pembelajaran pendidikan jasmani itu harus 
mencakup tujuan dalam domain psikomotorik, domain kognitif, dan tak kalah pentingnya dalam domain afektif. Permainan tembak kaleng ini mempunyai banyak keunggulan sehingga perlu diujicobakan sebagai alternatif variasi permainan bola kecil dalam pembelajaran Penjasorkes kelas VIII SMP N 6 Tebing Tinggi.

Produk yang dihasilkan melalui penelitian pengembangan ini berupa model permainan alternatif variasi permainan bola kecil dalam pembelajaran Penjasorkes yang sesuai dengan karakteristik siswa sekolah menengah pertama, yang dapat mengembangkan semua aspek pembelajaran (kognitif, afektif, psikomotor) secara efektif dan efisien, serta dapat meningkatkan intensitas fisik sehingga kebugaran jasmani dapat terwujud, serta dapat mengatasi kesulitan dalam pengajaran permainan bola keci. Efektif yaitu sesuai dengan produk yang diinginkan, dan efisien yaitu sesuai dengan yang seharusnya dilakukan atau sesuai dengan yang ingin dicapai.

Penelitian ini merupakan penelitian pengembangan yang bertujuan menghasilkan produk berupa model pembelajaran bola kecil bagi siswa Sekolah Menengah Pertama (SMP). Menurut Borg dan Gall dalam Sugiyono (2009:9), Penelitian dan pengembangan merupakan metode yang digunakan untuk mengembangkan atau memvalidasi produk- produk yang digunakan dalam pendidikan dan pembelajaran.

Dalam suatu penelitian tentunya mempunyai permasalahan yang perlu diteliti dan dianalisis untuk memecahkan permasalahan. Setelah mencermati dari latar belakang tersebut di atas, maka permasalahan yang akan dikaji adalah : "Bagaimana model pengembangan permainan "Tembak Kaleng” sebagai alternatif variasi permainan bola kecil dalam pembelajaran Penjasorkes bagi siswa kelas VIII SMP N 6 Tebing Tinggi Tahun 2017?

Sesuai dengan permasalahan yang diajukan diatas, maka tujuan pengembangan ini adalah untuk menghasilkan produk model permainan "Tembak Kaleng” sebagai alternatif variasi permainan bola kecil dalam pembelajaran Penjasorkes bagi siswa kelas VIII SMP N 6 Tebing Tinggi Tahun 2017.

\section{METODE PENELITIAN}

Analisis kebutuhan merupakan langkah awal dalam melakukan penelitian ini. Langkah ini bertujuan untuk menentukan apakah model pembelajaran permainan ini dibutuhkan atau tidak. Pada tahap ini peneliti mengadakan observasi di SMP N 6 Tebing Tinggi tentang pelaksanaan olahraga bola kecil dengan cara melakukan pengamatan tentang proses pembelajaran.

Berdasarkan hasil analisis kebutuhan tersebut, maka langkah selanjutnya adalah pembuatan 
produk model permainan bola kecil. Dalam pembuatan produk yang dikembangkan, peneliti membuat produk berdasarkan kajian teori yang kemudian dievaluasi oleh satu ahli Penjas dan dua ahli pembelajaran. Subjek penelitian ini adalah siswa kelas VIII SMP N 6 Tebing Tinggi.

Pelaksanaan uji coba produk dilakukan melalui beberapa tahapan yaitu: (1) menetapkan desain uji coba sebanyak 2 kali, (2) menentukan subjek uji coba (8 siswa putra dan 8 siswi putri kelas VIII), (3) menyusun instrumen pengumpulan data, dan (4) menetapkan teknik analisis data.

Setelah uji coba produk, maka dilakukan revisi produk pertama hasil dari evaluasi ahli dan uji coba kelompok kecil sebagai perbaikan dari produk yang telah diujicobakan.

Hasil anaslisis uji coba skla kecil serta revisi produk pertama, selanjutnya dilakukan uji coba lapangan skala besar. Uji coba lapangan sekala besar ini dilakukan pada siswa VIII SMP N 6 Tebing Tinggi dengan jumlah siswa 34 yang tersiri dari 19 siswa putri dan 15 siswa putra.

Penelitian dilakukan pada semester I pada Bulan Agustus Tahun Pelajaran 2017/2018. Hasil akhir produk pengembangan dari uji lapangan yang berupa model pembelajaran bola kecil melalui permainan "Tembak Kaleng".

Dalam penelitian ini desain uji coba yang digunakan adalah desain eksperimental. Uji coba produk pengembangan melalui dua tahap, yaitu : Uji skala kecil (dilakukan pada 16 siswa), dan uji skala besar (dilakukan pada 34 siswa). Uji coba skala kecil dilakukan dengan 16 siswa, dimana akan dibagi menjadi 2 tim, satu tim berjumlah 8 orang. Dalam uji coba ini dilakukan 2 kali pertandingan. Uji coba skala besar dilakukan dengan 34 siswa, dimana akan dibagi menjadi 4 tim. Dalam uji coba ini dilakukan 4 kali pertandingan.

Subjek uji coba adalah sasaran pemakaian produk, yaitu siswa kelas VIII SMP N 6 Tebing Tinggi.

Jenis data yang dalam penelitian ini yaitu data kualitatif dan kuntitatif. Data kualitatif diperoleh dari hasil wawancara lisan maupun tulisan dari ahli penjas dan pakar pembelajaran penjas SMP sebagai bahan untuk revisi produk. Sedangkan data kuantitatif diperoleh dari kuesioner siswa.

Instrumen penelitian adalah alat atau fasilitas yang digunakan oleh peneliti dalam mengumpulkan data agar pekerjaannya lebih mudah dan hasilnya lebih baik, dalam arti lebih cermat, lengkap, dan sistematis sehingga lebih mudah diolah (Suharsimi Arikunto, 2006: 160). Instrumen yang digunakan dalam pengembangan produk menggunakan angket dan kuesioner. Angket digunakan untuk menjaring informasi secara sistematis dari ahli penjas dan pakar pembelajaran. Sedangkan kuesioner digunakan untuk mengetahui tingkat kelayakan produk. Alasan memilih kuesioner 
adalah jumlah subjek yang relatif banyak. Kuesioner yang digunakan untuk ahli berupa sejumlah aspek yang harus dinilai kelayakannya. Faktor yang digunakan dalam kuesioner berupa kualitas model permainan Tembak Kaleng. Serta komentar dan saran umum jika ada. Rentangan evaluasi mulai dari "tidak baik" sampai dengan "sangat baik" dengan cara dengan memberi tanda " $\sqrt{ }$ " pada kolom yang tersedia.

\section{HASIL PENELITIAN DAN PEMBAHASAN}

Hasil yang disajikan dalam penelitian pengembangan ini meliputi analisis kebutuhan, produk awal modifikasi permainan "Tembak Kaleng”, revisi produk awal modifikasi permainan "Tembak Kaleng", revisi produk akhir modifikasi permainan "Tembak Kaleng”, hasil produk akhir modifikasi permainan "Tembak Kaleng” serta efektivitas pengembangan permainan "Tembak Kaleng”.

Untuk mengetahui permasalahan- permasalahan pembelajaran yang terjadi di lapangan terutama berkaitan dengan proses pembelajaran pendidikan jasmani, serta bentuk pemecahan dari permasalahan tersebut, maka perlu dilakukan analisis kebutuhan. Kegiatan ini dilakukan dengan cara menganalisis proses pembelajaran yang terjadi sesunggahnya di lapangan, melakukan observasi pembelajaran dan melakukan studi pustaka/ kajian literatur. Sesuai dengan kompetensi dasar pada materi permainan bola kecil bagi siswa Sekolah Menengah Pertama, disebutkan bahwa siswa dapat mempraktikkan kombinasi teknuk dasar salah satu permainan dan olahraga beregu bola kecil lanjutan dengan kombinasi yang baik serta nilai kerjasama, toleransi, percaya diri, keberanian, menghargai lawan, bersedia berbagi tempat dan peralatan. Kenyataan yang ada dalam proses pembelajaran permainan bola kecil di Sekolah Menengah Pertama sering kali tidak dapat disampaikan dengan baik karena keterbatasan alat standar yang umumya tidak dimiliki oleh sekolah. Berdasarkan studi pendahuluan yang penulis lakukan di SMP $\quad \mathrm{N} \quad 6 \quad$ Tebing Tinggi, guru pendidikan jasmani sampai saat ini mengalami kendala dalam pelaksanaan pembelajaran permainan bola kecil karena belum tersedianya sarana prasarana yang memadai. Oleh karena itu diperlukan langkah kreatif untuk memodifikasi permainan tersebut menggunakan sarana dan prasana yang telah ada di sekolah agar semua kompetensi dasar dalam pembelajaran pendidikan jasmani dapat diajarkan pada siswa. Penelitian pengembangan permainan bola kecil pada siswa kelas VIII SMP N 6 Tebing Tinggi dilakukan dengan memberikan model baru permainan bola kecil pada pembelajaran pendidikan jasmani siswa Sekolah Menengah Pertama. Model baru dalam permainan bola kecil yang dikembangkan yaitu berkaitan dengan sarana prasaran dan peraturan 
yang digunakan dalam permainan bola kecil yang kemudian diberi nama permainan "Tembak Kaleng". Mengingat waktu yang dimiliki untuk melakukan praktek relatif pendek, paling tidak pendidikan jasmani diarahkan agar siswa memiliki kebugaran jasmani, kesenangan melakukan aktivitas fisik dan olahraga (gaya hidup yang aktif dan sehat), serta memperoleh nilainilai pendidikan yang diperlukan bagi siswa untuk bekal kehidupan sekarang maupun dimasa yang akan datang.

Ujicoba produk modifikasi permainan "Tembak Kaleng" kepada siswa kelompok kecil dilakukan dengan tujuan untuk mengetahui dan mengidentifikasi berbagai permasalahan seperti kelemahan, kekurangan, ataupun keefektifan produk saat digunakan oleh siswa. Data yang diperoleh dari uji coba ini digunakan bersama-sama dengan data masukan ahli sebagai pertimbangan untuk melakukan revisi produk sebelum digunakan pada uji coba lapangan skala kecil.

Uji coba lapangan skala kecil ini dilakukan pada siswa kelas VIII SMP $\quad \mathrm{N} \quad 6 \quad$ Tebing Tinggi yang berjumlah 16 siswa dengan 2 kali percobaan atau 2 inning. Pengambilan sampel dengan menggunakan metode sampel secara acak (random sampling). Selama melakukan uji coba lapangan skala kecil, penyampaian materi permainan "Tembak Kaleng" belum berjalan dengan lancar. Hal ini dikarenakan siswa masih merasa bingung pada saat mematikan pelari karena belum terbiasa. Setelah beberapa lama berjalan serta diberikan pengarahan para siswa mulai memahami peraturan sehingga permainan bisa berjalan dengan baik dan siswa siswi bisa menikmati permainan dengan riang gembira. Selain itu peniliti melakukan penilaian dari aspek psikomotorik, kognitif dan afektif yaitu dengan kuesioner Berdasarkan hasil kuesioner menunjukkan bahwa secara umum tanggapan siswa terhadap produk pembelajaran modifikasi permainan "Tembak Kaleng" yang diujicobakan kepada kelompok kecil termasuk katagori baik dengan bobot persentase skor 81,67\%. Jika ditinjau dari tiap-tiap aspek penilaian siswa terhadap produk pembelajaran modifikasi permainan "Tembak Kaleng" tersebut diperoleh gambaran bahwa pada aspek psikomotor yang diukur dengan 10 pertanyaan diketahui bahwa terdapat 6 item yang masih dalam kategori kurang baik yaitu nomor 1 tentang kemudahan "Tembak Kaleng" untuk dimainkan, nomor 3 tentag kemudahan dalam melemparkan bola, nomor 4 tentang kemudaha dalam menangkap bola, nomor 5 tentang kemudahan dalam menembak kaleng, nomor 6 tentang kemudahan dalam berpindah Base ke Base, nomor 7 tentang kemudahan dalam memperoleh angka/ poin,. Aspek kognitif yang diukur dengan 10 pertanyaan diketahui bahwa terdapat 1 item yang masih dalam kategori cukup baik yaitu nomor 4 tentang pengetahuan perlunya 
pemanasan sebelum memulai permainan. Aspek afektif yang diukur dengan 10 pertanyaan diketahui bahwa 1 item cukup baik yaitu nomor 8 tentang apakah seorang pemain boleh atau tidak menentng keputusan wasit. Hasil tersebut dapat dilihat pada grafik di bawah ini:

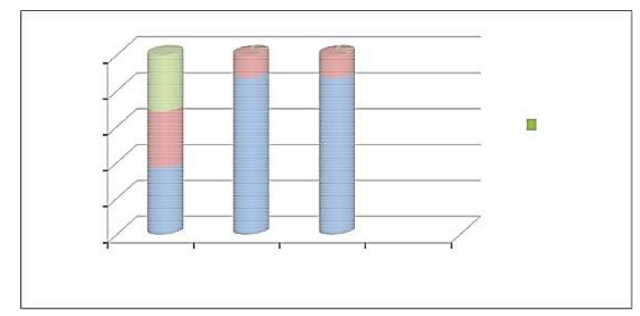

\section{Pembahasan}

Sesuai dengan kompetensi dasar pada materi permainan bola kecil khususnya materi bola kecil bagi siswa kelas VIII SMP N 6 Tebing Tinggi, disebutkan bahwa siswa dapat mempraktikkan kombinasi teknik dasar salah satu permainan dan olahraga beregu bola kecil lanjutan dengan kombinasi yang baik serta nilai kerjasama, toleransi, percaya diri, keberanian, menghargai lawan, bersedia berbagi tempat dan peralatan. Kenyataan yang ada dalam proses pembelajaran permainan bola kecil, di Sekolah Menengah Pertama seperti halnya di SMP N 6 Tebing Tinggi belum pernah diajarkan karena terbentur dengan sarana prasarana yang tersedia di sekolah yang tidak memadai sehingga banyak guru penjasorkes yang tidak menyampaikan materi permainan bola kecil kepada siswa. Penyampaian materi permainan bola kecil yang kepada siswa Sekolah Menengah Pertama sebenarnya tetap dapat dilakukan walau ketersediaan sarana prasarana di sekolah tidak memadai dengan melakukan berbagai modifikasi untuk sarana prasarananya menyesuaikan sarana prasarana yang telah ada disekolah dan menyederhanakan peraturannya. Untuk menjawab permasalahan yang ada dalam pembelajaran permainan bola kecil bagi siswa Sekolah Menengah Pertama Kelas VIII SMP N 6 Tebing Tinggi tersebut maka dalam penelitian ini dikembangkandan diujicobakan produk modifikasi permainan "Tembak Kaleng" yang dalam penyusunannya memperhatikan ketersediaan sarana prasarana yang ada di sekolah dan karakteristik siswa. Adapun hal-hal yang dimodifikasi tersebut diantaranya sarana prasarana seperti lapangan, penggunaan bola tonis, penggunaan susunan kaleng untuk memulai permainan dan Base plate. Selain modifikasi dari sarana dan prasarana, peraturan rounders yang sebenarnya juga dimodifikasi sesuai dengan karakteristik permainan "Tembak Kaleng”. Berbagai modifikasi yang dilakukan dalam permainan "Tembak Kaleng" dengan mempertimbangkan aspek ketersediaan fasilitas yang dimiliki sekolah dan pertumbuhan serta perkembangan fisik siswa tersebut ternyata mampu membawa perubahan dalam pelaksanaan pembelajaran permainan bola kecil pada siswa di mana berdasarkan hasil 
pengisian angket oleh siswa saat dilakukan uji coba lapangan diperoleh persentase skor tanggapan siswa secara umum dari seluruh aspek yaitu psikomotor, kognitif dan afektif masuk dalam kategori baik. Berdasarkan hasil tersebut maka dapat disimpulkan bahwa produk modifikasi permainan "Tembak Kaleng" yang telah dibuat layak digunakan untuk sebagai alternatif variasi permainan bola kecil dalam pembelajaran Penjasorkes bagi siswa kelas SMP N 6 Tebing Tinggi.

\section{SIMPULAN}

dan $\begin{array}{rr}\text { Berdasarkan hasil penelitian } \\ \text { pembahasan }\end{array}$ pengembangan model permainan Tembak Kaleng sebagai alternatif permainan bola kecil dalam pembelajaran Penjasorkes bagi siswa SMP N 6 Tebing Tinggi ini, maka dapat disimpulkan sebagai berikut:

a. Pengembangan model permainan Tembak Kaleng sebagai alternatif permainan bola kecil dalam pembelajaran Penjasorkes bagi siswa SMP N 6 Tebing Tinggi dinyatakan 90,39\% baik, berarti hasil ini dapat digunakan sebagai alternatif permainan bola kecil dalam pembelajaran Penjasorkes bagi siswa SMP N 6 Tebing Tinggi.

b. Pengembangan model permainan Tembak Kaleng sebagai alternatif permainan bola kecil dalam pembelajaran Penjasorkes bagi siswa SMP N 6 Tebing Tinggi mengindikasikan bahwa guru memiliki wawasan lebih luas mengenai pengembangan model permainan bola kecil dalam pembelajaran Penjasorkes, guru lebih kreatif dalam pengembangan sarana prasarana pembelajaran Penjasorkes serta dapat mendorong siswa lebih semangat dan meningkatkan antusiasme siswa salam mengikuti pembelajaran Penjasorkes.

\section{DAFTAR RUJUKAN}

Dadan, Heryana dan Giri Verianti. 2010. Pendidikan Jasmani Kesehatan dan Olahraga untuk Siswa SD-MI Kelas V. Online. Available at

Galih, Pangaji. 2017. Model Pengembangan Permainan Enjoy Volley Ball untuk Pembelajaran Penjas pada Siswa Kelas VII SMP N 1 Boja Kecamatan Boja Tahun 2017. Mulyasa. 2009. Kurikulum Tingkat Satuan Pendidikan. Bandung: PT. Remaja Rosdakarya Offset.

Samsudin. 2008. Pembelajaran Pendidikan Jasmani Olahraga dan Kesehatan SMP/MTS. Jakarta: PT Fajar Interpratama. Sugiyono. 2009. Penelitian Pendidikan. Bandung: Alfabeta.

Suharsimi Arikunto. 2006. Prosedur Penelitian Suatu Pendekatan Praktik. Jakarta: Rineka Cipta. 